\title{
Perceiving resilience: understanding people's intuitions about the qualities of air, water, and soil
}

\author{
Terre Satterfield ${ }^{1}$, Mary B. Collins ${ }^{2}$ and Barbara Herr Harthorn ${ }^{3,4}$
}

\begin{abstract}
Social-ecological-systems (SES) scholars have called for increased elaboration of the social dimensions of natural systems. Although a strong body of research explaining adaptive or maladaptive resource use exists, the integration of knowledge related to values, perceptions, and behaviors is less developed. Perceptions are particularly useful when one seeks a broad-scale view of the judgments that people implicitly or more automatically make in relation to nature and/or how people might rapidly and intuitively interpret the meaning of ecological status and change. Environmental perceptions are also distinct from the longer tradition of direct elicitation of environmental values as related to reported environmental behavior; and from understanding of perceived environmental health risks. Empirically, we thus explore what an architecture of environmental perceptions might be. Our goal is to advance an SESrelevant focus on the qualities that people intuitively assign to air, water, and soil in general and in particular. Initial qualities were first developed using mental model interview responses, which were then converted to psychometric rating scales administered across two surveys: an initial pilot survey and a large-scale follow up survey. In the pilot study, four factors-resilience, tangibility, complexity and sensory - emerged as primary $(n=697)$. In our large-scale follow up (U.S. nationally representative sample, $n=2500)$ we retested the two strongest factors (tangibility and resilience) within specific ecotypes or contexts (forests, rivers, oceans, deserts, urban, and rural). Resilience emerged a particularly powerful component of environmental risk perception, a factor comprising four attributes: recovers easily from human impacts, self-cleaning with time, mostly pure, and easy to control. Results suggest a greater mandate for explicit understandings of the intuitive foundations of perceived environmental risk as might explain environments we regard as vulnerable or resilient, healthy or not.
\end{abstract}

Key Words: environmental attitudes and values; environmental intuitions; perceived environmental impact; perceived environmental risks; perceived resilience; social-ecological systems

\section{INTRODUCTION}

Even a passing knowledge of the growing interdisciplinary field known as resilience studies and social-ecological-systems (SES) indicates the need to understand the interacting natural and social processes that explain why landscapes and seascapes persist in a healthy or degraded form (Berkes et al. 2003, McGinnis and Ostrom 2014). Constructs core to this understanding include ecological and social resilience (Thrush et al. 2009, Miller et al. 2010), regime change and the thresholds that mark such change (Folke et al. 2004), system vulnerability (Turner et al. 2003, Adger 2006), adaptive capacity (Armitage 2005, Engle 2011, Bennett et al. 2014), and the institutions and governance practices (formal and informal) in which management is nested (Ostrom et al. 1999, Lemos and Agrawal 2006, Durant and Fiorino 2017). Overall, experts agree that a coupled approach to understanding the resilience of human and natural systems is critical (Turner et al. 2003, Liu et al. 2007), and that a better understanding of the human dimensions of such coupled systems is particularly crucial (Schoon and Van der Leeuw 2015).

The call for greater attention to the social dimensions of natural systems includes the need to elaborate the already strong body of research explaining adaptive or maladaptive resource use in reference to common property norms, rules, property rights, and incentives (Ostrom et al. 1999, Adger 2006). More recently, there has been a call to explore the values, behaviors, and attitudes linked to specific places or things (e.g., a forest or river system, as they are impacted by environmental change; Castree et al. 2014).
Perceptions have also been identified as particularly important because they offer insight into how people intuitively understand and interpret the meaning of ecological status and change, thereby explaining support or rejection of conservation initiatives (Bennett 2016, Echeverri et al. 2017). Perceptions can also contradict the assessed health of physical features of a system thereby explaining why scientific reports of harm or safety fall on deaf ears (Marshall 2015). Understanding perceptions is thus useful when seeking a broad-scale view of those aspects of the natural world that people implicitly or more automatically attend to and why (e.g., what signals do we hear or see as information crosses our paths or rapid observation occur)? Although considerable research has been conducted on environmental values and attitudes, much less attention we find has been paid to perceptions of natural systems across the environmental social sciences, an observation also made in recent work by Bennett (2016).

Empirically, we thus explore what an architecture of perceptions of environmental phenomena might be. Our goal is to advance an SES-relevant focus on perceptions specific to how people might intuit different natural systems. By perceptions or intuitive judgments we mean the filters, heuristics, or rapid logics people use to evaluate the physical world around them. We approached this as an open empirical question. We thus moved from unstructured interviews to rating scales developed for survey applications. These were further informed by literatures on environmental values (Dietz et al. 2005, Kalof and Satterfield

${ }^{1}$ Institute for Resources, Environment and Sustainability, University of British Columbia, Vancouver, BC, ${ }^{2}$ Department of Environmental Studies, SUNY College of Environmental Science and Forestry, Syracuse, NY, ${ }^{3}$ Anthropology, UC Santa Barbara, CA, ${ }^{4}$ Center for Nanotechnology in Society, UC Santa Barbara, CA 
2005) and perceived environmental-health risks (Finucane et al. 2000, Bickerstaff 2004, Johnson and Covello 2012), as we deem this scholarship most useful to questions of how people think about environmental phenomena and why. To the extent that we depart from these literatures, we do so in three ways: we focus less on the many case studies used to explain how social-ecological systems work (e.g., in reference to small scale fisheries, see Basurto 2013, Kaplan-Hallam et al. 2017, grazing and pastoral economies or community forests, see Blythe 2015); or how we value high profile sites (e.g., national parks, threatened wild areas as the site of development projects such as mines or pipelines); or what value positions people hold or take on environmental controversies (e.g., those about endangered species, the burial of nuclear waste, or the acceptability of potable water; Pidgeon et al. 2008, Richardson and Loomis 2009).

Instead, our first steps toward the perception of natural systems are admittedly modest and seek to strip perceptions down to their basics. We avoid studying perceptions of iconic sites (e.g., the national park example) or problematic conditions (e.g., fishing declines or a superfund cleanup site). We begin instead with key environmental "media" as might an environmental scientist, that is: air, water, and soil; and then we consider perceptions of ecotypes: air, water, and soil in forests, rivers, oceans, and deserts, and in rural versus urban contexts. Our thinking is that an index or set of indices that might begin to reflect the basics of environmental perception will help explain why people see some natural systems as degraded, resilient, or vulnerable in the face of different impacts. We are also curious as to whether people are more sensitive to changes in the quality of water versus air versus soil. Do we care and respond easily, for instance, to impacts on visible water systems (freshwater or marine) but not to those involving terrestrial or air quality impacts?

\section{THEORETICAL INSPIRATION IN THE TRADITION OF RESEARCH ON PERCEPTIONS AND VALUES}

Two broad approaches address how people think about and/or perceive environmental phenomena: implicit versus explicit. Loosely, these are distinguished as directly ascertained in the form of stated preferences, attitudes, or values (Lockwood 1999, Gregory and Wellman 2001) versus semiconscious and rapidly assessed judgments (Leiserowitz 2007). The former direct approach, for example, what we value and why, has been particularly important to scholars of human-environment relations. These environmental values have been investigated in several ways, and are reflected in an enormous literature in its own right that cannot be given full treatment here. But primary among these is value-belief-norm theory (VBN; Stern et al. 1999, Oreg and Katz-Gerro 2006), which finds that we hold fundamental values that guide our beliefs and activate norms and the behavioral intentions linked to these (e.g., proenvironmental behaviors; Bamberg and Möser 2007). Similar values and beliefs have also been linked to the ecological risks we see as high priority and why (Slimak and Dietz 2006). Another school of thought has been concerned with what value is or exists in nature and what that means about our positions toward the natural world (Trainor 2006, O'Neill et al. 2007, Tadaki et al. 2017). Others still have investigated the ontological nature of value (utilitarian versus deontological; Sagoff 1998, 2007) and its measurement. For example, value in nature has been measured as biodiversity (Daily et al. 2000), as values held by individuals versus groups (Niemeyer and Spash 2001), or values whose meaning and measurement need be constructed as the values held or valuations assigned are found to be unstable or context specific (Fischhoff 1991, Warren et al. 2011, Failing et al. 2013). Debates about the intrinsic versus utilitarian value of nature (Chan et al. 2016) have also recently been challenged by more relational approaches that seek to link people and ecosystems via measures of tangible and intangible relationships to nature (Klain et al. 2017). Last, a very large body of scholarship considers alternatives to economic value and benefit-cost analysis in particular. Scholarship pertaining to the nonmarket value of natural goods and processes includes those who assign value equivalents to ecosystem processes, services, and their benefits (e.g., de Groot et al. 2002), and those who use choice experiments and other contingent valuation methods to ascertain worth, be that measured as dollars or other metrics (Klain et al. 2014, Naidoo and Ricketts 2006). In sum, scholarship on values has been primarily focused on explicit elicitation of values we hold and valuations we assign or that can be inferred, however much methodological approaches vary.

Implicit approaches, conversely, remain somewhat rare outside energy and climate research (Reddy et al. 2017). By this (implicit), we mean approaches that assume that judgements about what we like or dislike, attributes we attend to or ignore, are made rapidly even automatically. Such rapid evaluations are based on heuristics that allow us to quickly filter the vast amounts of information that we are faced with in daily life (Gilovich et al. 2002, Kahneman 2003). Cognitively speaking, this enables us to efficiently reduce or manage that complexity (Levine et al. 2015). Implicit judgments are also thought to be better at predicting behavior. This is because we may report no explicit or stated attitudes against, for example, ethnic or racial groups different from our own, but when tested implicitly, evidence of biases occur (Axt et al. 2014). For this reason, implicit association tasks are widely used in psychology to address invisible or latent biases of all kinds (including those pertaining to race, gender, consumer goods, etc.; Greenwald et al. 2009).

To the extent that implicit or intuitive judgments are used to understand human-environment research, they involve a few very recent studies on implicit associations and sensory impressions and a richer longer-standing body of work on risks to human health as a function of environmental hazards. To the first, more recent work, one study compares implicit versus explicit preferences for endangered species and biomes as might affect conservation intentions (Echeverri et al. 2017), and another uses perceptions (defined as sensory observations and subjective evaluations more broadly) to ascertain priorities for marine conservation (Bennett 2016). A third and also recent study finds an implicit prevalence or taxonomic bias across scientific research activity, suggesting that less charismatic species are possibly ignored because of underlying preferences (Troudet et al. 2017).

There does exist, however, a long-standing body of work that offers important parallels for the study of perception of environmental phenomena (Keller et al. 2012). In a now classic study of perceived risk, rapid assessments of different risk objects (e.g., nuclear waste) revealed that the qualities of a technological hazard were highly predictive of which would be regarded as posing high risk to human health. Using intuitive and rapidly applied psychometric rating scales, two groups of qualities or factors were predictive: dread risk (i.e., technology was seen as dreaded, uncontrollable, as holding catastrophic potential, etc.) 
and unknown risk (seen as unknown to science, to those exposed, and not observable, etc.; Hohenemser et al. 1986, Slovic 1987, 2000). Such factors have remained predictive as new risk objects are tested (Siegrist et al. 2007, Satterfield et al. 2009, Bodemer and Gaissmaier 2015), and often regardless of mortality or morbidity statistics that designate hazards as comparatively safe (Knuth et al. 2014). Subsequent work on perceived risk has found that environmentally hazardous technologies are also viewed as risky when management is seen as not trustworthy (Poortinga and Pidgeon 2005), and where harms are seen as inequitably distributed (Conti et al. 2011). The affective dimensions of information processing constitute a central theoretical premise in more recent work as these explain rapid judgments where, for example, the positive or negative affective valence assigned a risk object (e.g., GMOs) predicts its evaluation as risky (to human health) or not (Loewenstein et al. 2001). Last, differences in political and group loyalties are a powerful predictor of perceived risk (Kahan 2010) as is the demographic profile of the perceiver, which can be explained by world views (Flynn et al. 1994). High income earning and highly educated white males perceive most hazards as less risky than do all other socioeconomic groups, but much of that gender and racial difference in perception can be explained by support for egalitarian versus hierarchical social systems (Finucane et al. 2000) and by perceptions of vulnerability and justice (Satterfield et al. 2004).

Oddly, however, and despite many insights as to how people judge the health risk implications of specific hazards (e.g., Cobb 2005, Macoubrie 2006, Siegrist et al. 2007), very little of this focus has involved evaluations of or perceptions of environmental harms. By this we mean that very few studies, using implicit or intuitive designs (versus value-based ones), have focused on public perceptions of the environment or its physical components as the express object of impact. We could find only one early and important example of characterizing what the authors referred to as "ecological risk perceptions," which they found were based on judgements about which species were impacted, the degree of human benefits or impacts present, and the state of knowledge about those benefits (McDaniels et al. 1995). More recently, Scheufele et al. (2007) and Priest and colleagues (2006, 2011) examined the perceived risk to the environment of nanotechnologies. In the former case, experts were more concerned about environmental impacts than were public groups; in the latter study, it was concern about societal risks (e.g., who might benefit or not benefit from these technological innovations) that prevailed relative to other classes of impact, including the environment. Most studies have instead (the authors of this paper included) asked survey respondents to evaluate the risks of a range of environmental hazards, be they posed by nanotechnologies, genetically modified organisms, or climate change, because they are seen to be a serious problem in general (Marshall et al. 2011), to pose risks to you or your family (Leiserowitz 2007), or pose risks to human health, safety, or prosperity (Kahan 2014). In these studies, that is, perceived risks to human health are the primary object of consequence, however much the vector of harm might be different environmental media, such as contaminated water. As well, many good studies exist about the monitoring of air or water quality (Arshad et al. 1996, Chapman and WHO 1996, WHO 2000, Reche et al. 2011), and of public perceptions of air quality as it pertains to quality or life and/or particulate-matter indices (Williams and Bird 2003, Bickerstaff 2004).
To summarize, across these kindred bodies of work, questions about perceived risks to air, water, or soil generally address contaminants within air or water as specific to human health, and not more ontological basics about what kind of "thing" air, water, or soil is (e.g., what qualities they have) and how we perceive or detect harm to these environmental contexts. Risk perception work has also not yet operationalized some key constructs in the environmental social sciences: constructs such as resilience, which addresses the capacity of human-ecological regimes to absorb the impact of stressors without undergoing a shift into a new system state (Folke et al. 2004, Thrush et al. 2009). We know comparatively little outside the robust tradition of values and norms research (Stern 2000) as well as traditional knowledge studies (Berkes et al. 1995, Ingold 2000), that help us explain perceiving human agents, how we detect system change, and if we are numb or sensitive to particular changes. Nor do we know, for example, if or why a landscape or body of water on the brink of an undesirable regime shift will be perceived as in peril or not, worthy of attention or not. In short, in no case that we could find has risk perception research characterized the underpinning logics or intuitive rules-of-thumb that people might use to rapidly assess the quality of environmental phenomena. Nor has any work that we could find asked what basic constructs or factors might be derived that help explain how we implicitly detect the quality of these environmental media and what this means for understanding perceived risks posed to these fundamental environmental contexts.

Our research questions for developing this line of thinking were thus as follows:

1. Upon converting open-ended thinking from interviews to a set of psychometric ratings, do they coalesce into a coherent set of factors that capture how people intuitively characterize air, water, and soil $(\mathrm{n}=697)$ ?

2. Are the factors robust from the point of view of variance explained, and are they also prima facie discrete, that is, do they have construct validity?

3. Do any factors derived hold up to further testing on a nationally representative sample of U.S. respondents $(n=$ 2500)?

4. As air, water, and soil are somewhat abstract media, do we find different patterns of perception when specifying these by ecotype (e.g., forests, rivers, oceans, deserts, urban and rural contexts)?

5. Last, are there demographic differences across perceptions, especially those pertaining to gender and race?

\section{METHODS}

Two surveys comprise the primary data collection for this work: a convenience panel sample $(n=696)$ to characterize initial perceptions (research questions 1 and 2) and a U.S. nationally representative second survey $(n=2500)$ to retest initial findings in general and in reference to specific ecotypes in the form of air, water, and soil found in ocean, desert, river, forest, urban and rural environments. Question sets are described below; each block of questions was randomized to minimize response order effects. Our methods were reviewed by the University of California at Santa Barbara Human Subjects Committee and institutional review board (IRB) approvals were issued for protocols 15-10-170 and 16-10-591. 
Table 1. Initial psychometric rating scale. Participants were asked to quickly mark the box closest to the wording describing how they think about [air, water, or soil]. Contrasting endpoint design was modeled after prior hazard risk studies.

\begin{tabular}{|c|c|c|c|c|c|c|c|}
\hline Something that's Everywhere & $\square$ & $\square$ & $\square$ & $\square$ & $\square$ & $\square$ & Something that's in Relatively Contained Spaces \\
\hline Easy to Measure & $\square$ & $\square$ & $\square$ & $\square$ & $\square$ & $\square$ & Difficult to Measure \\
\hline Can be Touched or Felt & $\square$ & $\square$ & $\square$ & $\square$ & $\square$ & $\square$ & Cannot be Touched or Felt \\
\hline Easy to Describe & $\square$ & $\square$ & $\square$ & $\square$ & $\square$ & $\square$ & Difficult to Describe \\
\hline Easy to Sample and Test & $\square$ & $\square$ & $\square$ & $\square$ & $\square$ & $\square$ & Difficult to Sample and Test \\
\hline Easy to Control & $\square$ & $\square$ & $\square$ & $\square$ & $\square$ & $\square$ & Difficult to Control \\
\hline Mostly Pure & $\square$ & $\square$ & $\square$ & $\square$ & $\square$ & $\square$ & Mostly Contaminated \\
\hline Recovers Easily from Human Impacts & $\square$ & $\square$ & $\square$ & $\square$ & $\square$ & $\square$ & Recovers Poorly from Human Impacts \\
\hline Self-Cleaning with Time & $\square$ & $\square$ & $\square$ & $\square$ & $\square$ & $\square$ & Needs Human Intervention to Become Clean \\
\hline Full of Micro Life Forms & $\square$ & $\square$ & $\square$ & $\square$ & $\square$ & $\square$ & Empty of Micro Life Forms \\
\hline Relatively Complex & $\square$ & $\square$ & $\square$ & $\square$ & $\square$ & $\square$ & Relatively Simple \\
\hline A Very Mobile Thing & $\square$ & $\square$ & $\square$ & $\square$ & $\square$ & $\square$ & A Very Stationary Thing \\
\hline A Relatively Thin Substance & $\square$ & $\square$ & $\square$ & $\square$ & $\square$ & $\square$ & A Relatively Thick Substance \\
\hline Visible & $\square$ & $\square$ & $\square$ & $\square$ & $\square$ & $\square$ & Invisible \\
\hline Has a Distinct Smell & $\square$ & $\square$ & $\square$ & $\square$ & $\square$ & $\square$ & No Distinct Smell \\
\hline Has a Distinct Taste & $\square$ & $\square$ & $\square$ & $\square$ & $\square$ & $\square$ & No Distinct Taste \\
\hline
\end{tabular}

\section{Survey design}

Psychometric rating scales (scales with contrasting endpoints) modeled on prior hazard risk studies typically asked participants to rapidly identify the descriptive point on the scale closest to her/ his thinking. One widely applied scale in early risk perception work asked, for instance, that people use a 6-point scale to quickly rate nuclear power as "well understood by scientists" versus "not well understood by scientists" or "highly dreaded" versus "not at all dreaded."

Using an analogous logic, we converted wording from open-ended interview questions to 16 scales. Interviewees were selected for diversity and drawn from multiple networks across the two cities in which the authors lived. There are far too many interview wordings to portray here, thus a few sample responses only are provided, as is their conversion to necessarily brief scales:

Question: "What comes to mind when you think about air, water, and soil? What are its properties or characteristics?"

Sample of open ended interview responses:

a. [Air] is: "everywhere, it's pervasive, you can't escape air";

b. [Soil]: "It's full of things: "bugs," "plants," and "the like."

c. Or, referencing air, water, and soil together: "You have to breathe in air every day and drink water. Soil has to do with food, but it is distant for me." Air and water is "more known or easier to understand, and is more identifiable, more relevant than soil, unless you're a farmer." Or, "air is diffuse and fast-moving, water is liquid and possesses a moderate mobility, and soil is solid and the least mobile."

Commensurate scales became:

a. For pervasive: "something that's everywhere/something that's in relatively contained spaces";

b. For full of things: "full of micro life forms/empty of micro life forms";

c. For easy to understand and for diffuse, mobile, and solid: "easy to describe/difficult to describe." And "a very mobile thing/a very stationary thing."
Open-ended elicitations regarding how people perceive harm to environmental media included questions such as: "Do you think of any of these environmental media as more susceptible than the others to contamination? Why? What kinds of things affect the quality of air, water, and soil? And, how can you tell whether [air, water, or soil] are contaminated?"

Sample answers:

a. "Well, they're all, they're interconnected, they rely on each other.... air needs trees to clean it, and water evaporates and forms clouds in the air, and the whole system relies on everything in it."

b. "I think that contaminated sites can never be fully remediated? I think it's a time scale of many human generations to return contaminated soil to its original state, we do what we can but we really can't remediate to ... we can't remove everything."

These were converted to scales such as:

a. Relatively complex/relatively simple.

b. Self-cleaning with time/needs human intervention to become clean.

And recovers poorly from human impacts/recovers easily from human impacts.

The full initial rating scale, provided in Table 1, began with a root question asking study participants to quickly mark the box closest to the statement describing how they think about [air, soil, or water]. "Air" for example read as follows, as did equivalents for water and soil:

Question Text: Below are a number of contrasting phrases used to describe air [or water or soil]. Mark the box that is closest to the statement that describes how you think about air. Please answer these quickly and trust the first answer that comes to mind. [For example, if you really agree with the description on the left, mark the furthest left box. If your agreement is a bit weaker than that, mark the next one over, and so on. ]. 


\section{Study 2 design}

Our second survey used the same protocol modified to include only those items that loaded onto two primary study 1 factors, described below. We thus excluded in the second survey, the last six items in the above battery of scales. We added a new scale with the endpoints "healthy" and "unhealthy." And because our interest was perception, we added a few questions that addressed use of one's senses more directly when detecting the safety of environmental media. Specifically, we provided a question introduction that read: "We often use our senses of smell, taste, sight, and touch to make sure air, water, or soil is safe." Thereafter, we asked respondents whether they "think that, combined, the human senses in general are very good to very poor at helping you detect the safety of [air], [water], or [soil]," asking each separately. A five-point scale was provided reading very good, good, neither good nor poor, poor, very poor.

Study 1 data collection:

Survey 1 was conducted by a third-party survey-research organization (Decision Research), using a U.S. public panel established for completing web-based surveys. It was approximately 20 minutes in length. The items reported here appeared before any other questions. The balance of the survey addressed attitudes toward emerging technologies and are being prepared for publication. We described the survey as being about "specific aspects of the environment such as air, water, or soil. Other questions will ask you about the benefits and risks of technologies, both current and future ones." The panel, and sample frame, were as closely matched to U.S. census data as reasonably possible. We consider this a convenience sample suitable for such exploratory conceptual research because it is web-based, closely but not precisely matched to U.S. census data, and it is a precondition that participants have online access and are sufficiently literate or better. More females than males also tend to volunteer for research of this kind. The exact match of the panel's sample frame with the U.S. population is provided in Table 2, as are the demographics of the sample for this study. Every reasonable effort was made to encourage participation. Further, a reasonable effort was made to ensure that all respondents included in our study answered the questionnaire faithfully. Because no web-based controls were possible (minimum page or time limit requirements, etc.), all respondents who completed the entire survey in less than 10 minutes were removed to eliminate respondents unlikely to have read questions with reasonable care. This resulted in a total sample of $n=697$.

When available, demographic detail for each study participant was provided by the survey research company. The mean age of respondents was 42 years, with $52 \%$ women and $48 \%$ men. Seventy-three percent of participants self-reported as "white," $21 \%$ as nonwhite, $6 \%$ refused to answer this question. The survey was conducted in English. In general, our sample has a few notable differences from the U.S. population at large and consistent with panel surveys where working access to and familiarity with webbased systems is required. This included lower than average representation of respondents with less than a high school education ( $1 \%$ of respondents versus $15 \%$ nationally); and higher than average representation of those reporting as college graduates ( $40 \%$ of survey respondents versus $26 \%$ nationally). Differences also likely reflect a bias in favor of English, and in favor of the technology-centric nature of the topic.
Table 2. Characteristics of respondents participating in survey 1. Sample derived from web-based panel provided by Decision Research. Members were as closely matched to U.S. census data as reasonably possible resulting in total sample of $n=697$ with higher than average proportion of college graduates, and younger than average U.S. population.

\begin{tabular}{lcc}
\hline \hline & $\begin{array}{c}\text { Distribution of } \\
\text { U.S. Population } \\
\text { (over 18) }\end{array}$ & $\begin{array}{c}\text { Distribution of } \\
\text { Study } \\
\text { Respondents } \\
\text { (N = 697) }\end{array}$ \\
\hline Gender (\% female) & $52 \%$ & $52 \%$ \\
Race & $77 \%$ & $73 \%$ \\
White & $23 \%$ & $21 \%$ \\
Nonwhite & NA & $6 \%$ \\
Refused to answer & & $1 \%$ \\
Education & $15 \%$ & $27 \%$ \\
Less than high school & $30 \%$ & $32 \%$ \\
High school diploma or GED & $29 \%$ & $40 \%$ \\
Some College & $26 \%$ & \\
College graduate or more & & $24 \%$ \\
Age & $20 \%$ & $47 \%$ \\
18 to 30 & $36 \%$ & $27 \%$ \\
31 to 50 & $31 \%$ & $2 \%$ \\
51 to 70 & $13 \%$ & 42 years \\
Over 70 & & \\
Mean age & & \\
\hline
\end{tabular}

Study 2 data collection

The second round of data collection occurred in late 2012 and was conducted by YouGov, an internet-based data collection and analytics firm that operates internationally, and is widely used among academic researchers for panel-based survey research. For this study, they delivered the survey instrument to 2768 respondents who were then matched down to a sample of 2500 U.S. residents to produce the final dataset. The final dataset includes a general population sample of 2000 and oversamples of 250 African Americans and 250 Hispanics to ensure our ability to compare racial variation across results. Each group was matched on gender, age, race, education, party identification, ideology, political interest, and census region. YouGov then weighted the matched set of survey respondents to known marginals for each group drawn from the 2007 American Community Survey. The dataset includes two weights: weights within each of the three sample groups (general population and two oversamples), and weighting the entire sample of 2500 to general population parameters. The marginals used for each group are shown in Table 3 below. All data reported within is weighted; split sampling on some question sets is reported in situ in the results sections below.

\section{RESULTS}

Characterizing the perceived qualities of air, water, and soil

To elucidate latent characteristics or factors represented by the items included in the 16 rating scales above, we conducted a principal components analysis (PCA), a data minimization technique. This allowed us to isolate the intuitive logics or qualities that participants use to perceive the status of air, water, and soil. In general, people agreed more fully with the left side of the rating 
Table 3. Characteristics of respondents participating in survey 2. $\mathrm{N}=2500$ U.S. residents. Includes a general population sample of 2000 and oversamples of 250 African Americans and 250 Hispanics to ensure variation across results. The weighted dataset includes two weights within each of the three sample groups (general population and two oversamples), and weighting of the entire sample of 2500 to general U.S. population parameters.

\begin{tabular}{lc}
\hline \hline & $\begin{array}{c}\text { Distribution of Study Respondents } \\
\text { Weighted to U.S. Population } \\
\text { (N = 2500) }\end{array}$ \\
\hline Gender (\% female) & $51.3 \%$ \\
Race & \\
White & $75.7 \%$ \\
Nonwhite & $11.4 \%$ \\
Black & $12.9 \%$ \\
Hispanic & \\
Education & $46.7 \%$ \\
Less than high school & $\mathrm{NA}$ \\
High school diploma or GED & $28.7 \%$ \\
Some College & $24.6 \%$ \\
College graduate or more & \\
Income & $44.4 \%$ \\
Less than \$50,000 & $26.8 \%$ \\
\$50,000-\$100,000 & $16.8 \%$ \\
Over \$100,000 & $12 \%$ \\
Prefer not to say & \\
Age & \\
18 to 29 & $22.1 \%$ \\
30 to 44 & $28.1 \%$ \\
45 to 64 & $33.2 \%$ \\
Over 65 & $16.5 \%$ \\
\hline
\end{tabular}

scales, most of which emphasize the ease with which air, water, or soil can be cognitively discerned (e.g., "easy to measure") or are seen as robust (e.g., recovers easily from impacts). The 16 items had a Chronbach's alpha equal to 0.788 , a high level of internal consistency indicating that it is suitable to conduct the PCA. Component loadings are presented in Figure 1 and Table 4, along with names for these factors. Of the 16 items used to estimate our 4-factor solution, 14 had high enough loading to be included in the generated factors, based on a loading cut off of $0.5 \mathrm{met}$, which is common for this type of analysis. We used a Varimax rotation because this rotation assumes an orthogonal relationship between items and results in factors that are uncorrelated with one another. Varimax rotation is also commonly used in social science survey research because it often results in more interpretable factors (Kaiser 1974).

As shown in Table 4, 14 items can be grouped into four factors that can be used to characterize some initial qualities of air, water, and soil. We label and interpret these factors as (1) the environment as tangible; (2) the environment as resilient; (3) the environment as complex; and (4) the environment's sensory nature. Tangibility is the sense that environmental media are ubiquitous ("something that's everywhere"), and amenable to measurement and detection ("easy to sample and test; measure; and can be touched or felt; and described"). The second factor, accounting for $25 \%$ of the variance, is labelled here as resilience because it captures some (though not all as discussed below) of the qualities that ecologists reference by this term: the ability for a system (or in this case air, water, and soil) to respond to perturbations or disturbance (Folke et al. 2004). This is best expressed by the combination of scaled descriptors that capture these media as more or less "able to recover easily from human impacts, easy to control, as relatively pure, and as self-cleaning with time." The last two somewhat weaker factors account for $43 \%$ of the remaining variance and are comparatively inchoate. For example, the third factor is somewhat opaque, at face value, and includes ideas of environmental media as relatively complex, full of micro life forms, and mobile; and the fourth factor comprises only two items, which is generally considered insufficient for a factor, but nonetheless captures the extent to which air, water, and soil are considered distinguishable by two human senses: smell and taste.

Fig. 1. Principal components analysis factor space. The PCA factor space shows the "perceptual map" of how people conceive of the environment, defined here by its most coarse scale raw materials: air, water, and soil. We show that although overlaps exist (which is expected when measuring a complex topic), four distinct factors emerge: resilience, tangibility, complex, and sensory. The average loadings summarize the items (listed on the outer ring of the space), which make up each factor. For an item to be included in a factor it had to have a loading of greater than 0.5 . Within the solution, resilience $(25 \%)$ and tangibility (33\%) factors explain more of the variance than do the complex $(23 \%)$ or sensory $(20 \%)$ factors.

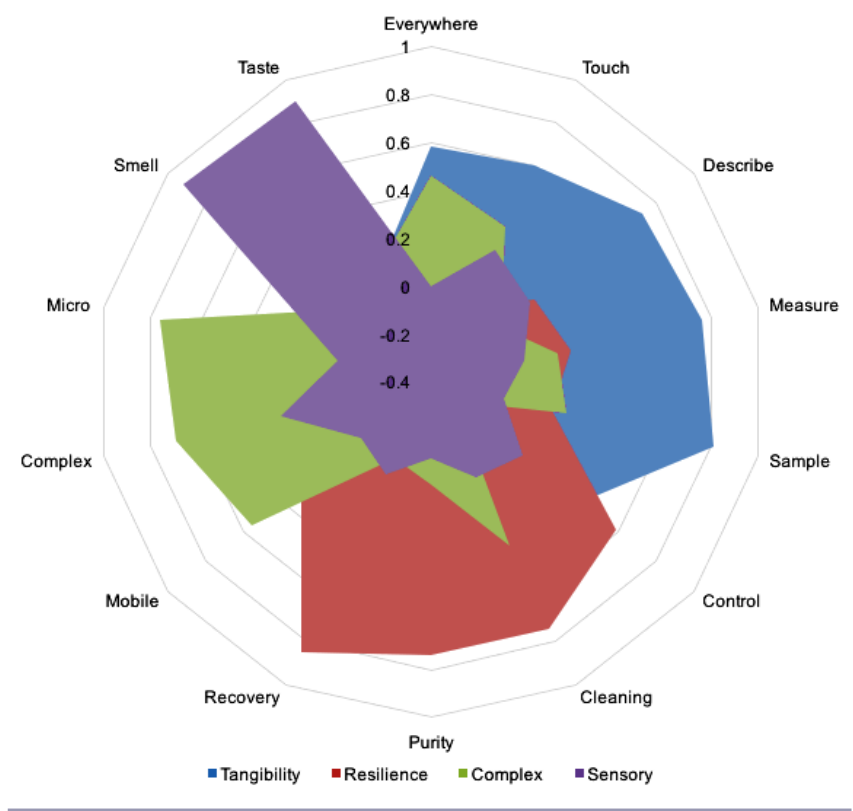

\section{Perceiving resilience: study 2}

Our second, U.S., nationally representative survey sought to (a) further test two of the original factors using a more representative sample of respondents $(\mathrm{n}=2500)$; $(\mathrm{b})$ pay close attention to resilience as a more intuitively interesting factor given its implied characterization about the qualities of the environmental contexts tested; and (c) introduce new contexts to reduce the abstraction of the original design by introducing the aforementioned five ecotypes: forest, river, ocean, desert urban and rural water, soil, 
Table 4. Principal components analysis results including factor loadings for air, water, and soil psychometric appraisals.

\begin{tabular}{|c|c|c|c|c|c|}
\hline & $\begin{array}{c}\text { Factor 1: } \\
\text { Tangibility } \\
\text { 33\% Variance } \\
\text { Explained }\end{array}$ & $\begin{array}{c}\text { Factor 2: } \\
\text { Resilience } \\
\text { 25\% Variance } \\
\text { Explained }\end{array}$ & $\begin{array}{c}\text { Factor 3: } \\
\text { Complicate/ } \\
\text { Ephemeral } \\
23 \% \text { Variance } \\
\text { Explained } \\
\end{array}$ & $\begin{array}{c}\text { Factor 4: Sensory } \\
\text { 20\% Variance } \\
\text { Explained }\end{array}$ & \\
\hline Something that's Everywhere & 0.58 & - & - & - & $\begin{array}{l}\text { Something that's in Relatively } \\
\text { Contained Spaces }\end{array}$ \\
\hline Easy to Measure & 0.76 & - & - & - & Difficult to Measure \\
\hline Can be Touched or Felt & 0.60 & - & - & - & Cannot be Touched or Felt \\
\hline Easy to Describe & 0.73 & - & - & - & Difficult to Describe \\
\hline Easy to Sample and Test & 0.81 & - & - & - & Difficult to Sample and Test \\
\hline Easy to Control & - & 0.59 & - & - & Difficult to Control \\
\hline Mostly Pure & - & 0.74 & - & - & Mostly Contaminated \\
\hline $\begin{array}{l}\text { Recovers Easily from Human } \\
\text { Impacts }\end{array}$ & - & 0.85 & - & - & $\begin{array}{l}\text { Recovers Poorly from Human } \\
\text { Impacts }\end{array}$ \\
\hline Self-Cleaning with Time & - & 0.74 & - & - & $\begin{array}{l}\text { Needs Human Intervention to } \\
\text { Become Clean }\end{array}$ \\
\hline Full of Micro Life Forms & - & - & 0.76 & - & Empty of Micro Life Forms \\
\hline Relatively Complex & - & - & 0.69 & - & Relatively Simple \\
\hline A Very Mobile Thing & - & - & 0.56 & - & A Very Stationary Thing \\
\hline Has a Distinct Smell & - & - & - & 0.92 & No Distinct Smell \\
\hline Has a Distinct Taste & - & - & - & 0.90 & No Distinct Taste \\
\hline
\end{tabular}

and air. We also wanted to consider demographic differences in perception, anticipating some variation across gender and race given prior risk research (Finucane et al. 2000).

A second two-factor solution (tangibility and resilience) in this new survey also explained $59 \%$ of the total variance, $30 \%$ under the factor tangibility and $29 \%$ of the variance explained by the factor resilience (see Table 5). Using the more representative and robust sample provided by survey 2 , the loadings within each factor are strong, with four of six items sitting at 0.7 or higher in factor 1 (tangible), and four of five sitting at 0.7 or higher in factor 2 (resilience).

Examining the tangibility of ecotypes

Further analysis across ecotypes provides both prosaic and intriguing observations. Comparing mean scores for air, water, and soil reveals, unsurprisingly, that across all ecotypes soil $(M=$ 24.1), and water $(M=23.5)$ are more tangible than is air $(M=$ 14.2). By tangible, we mean the components: visible; amenable to description and measurement; touchable; and describable. Forest water is perceived as the most tangible $(M=23.1)$ and desert water is perceived as the least tangible $(M=20.6)$, a possible conflation with scarcity or inaccessibility discussed below. Similarly, forest soil is perceived as the most tangible $(M=23.7)$ and ocean bed soil is perceived as the least tangible $(M=19.6)$. The mean score variation suggests that we do intuit the presence and tangibility of each ecotype differently, with some media perceived as understandably elusive (e.g., desert water).

\section{Examining the resilience of ecotypes}

Resilience (Fig. 2), again, comprises a set of variables that reflect how healthy or not a system is perceived to be, whether it is seen as recovering well or poorly from human impacts, whether it is contaminated or pure and whether it requires human intervention to become clean. When examining resilience, across ecotypes, the air, water, and soil of forested systems are perceived as significantly more resilient (at $p<0.05$ or better) than are the same media in all other ecotypes. For example, the mean score for the resilience of forest air is $M=15.9$, whereas ocean air is $M=$ 12.7 and city air is $M=8.2$. Ocean bed soil, river bed soil, and city soil are also less resilient than forest soil, and a similar pattern is again true for air across ecotypes.

Fig. 2. Average perceived resilience score across ecotypes. Air, water, and soil of forested systems are perceived as significantly more resilient than are the same media in all other ecotypes. Ocean bed soil, river bed soil, and city soil are also perceived as less resilient than forest soil. A similar pattern is again true for air across ecotypes.

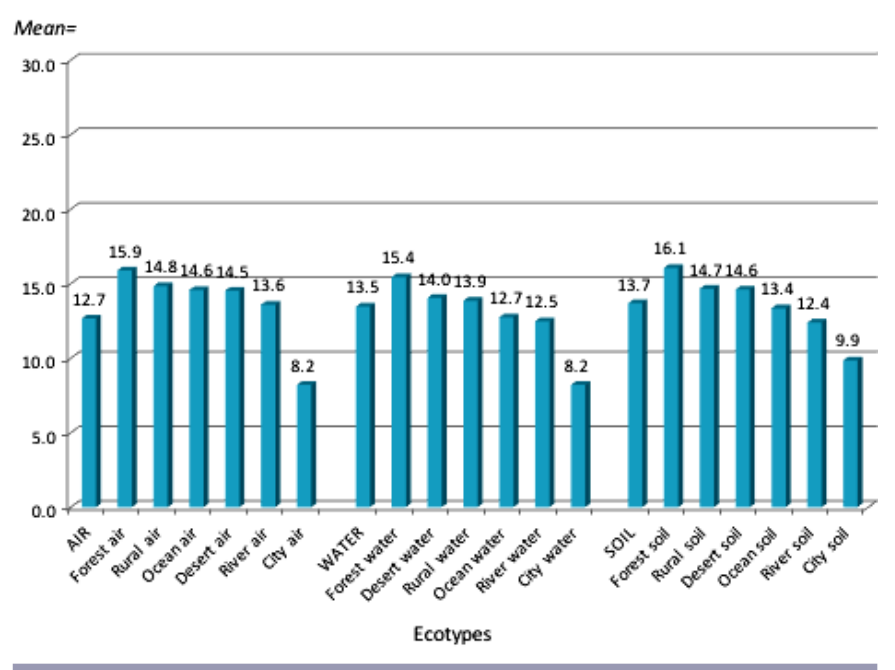

Gender, race, and environmental perception

We also examined the perceived resilience of air, water, and soil across ecotypes by race and gender. White males as well as African, Latino, and Asian males consistently rate the air, water, and soil 
Table 5. Perceived tangibility and resilience. Survey 2 provided a two-factor solution (tangibility and resilience) and explained 59\% of the total variance, $30 \%$ under the factor "tangibility" and $29 \%$ of the variance explained by the factor "resilience".

\begin{tabular}{lccl}
\hline \hline & Tangible & Resilience & \\
\hline Easy to sample and test & 0.794 & 0.201 & Difficult to sample and test \\
Can be touched or felt & 0.764 & 0.101 & Cannot be touched or felt \\
Easy to measure & 0.755 & 0.268 & Difficult to measure \\
Easy to describe & 0.702 & 0.248 & Difficult to describe \\
Visible & 0.676 & 0.201 & Invisible \\
Full of micro life forms & 0.576 & 0.087 & Empty of micro life forms \\
Healthy & 0.327 & 0.719 & Unhealthy \\
Easy to control & 0.297 & 0.601 & Difficult to control \\
Self-cleaning with time & 0.211 & 0.779 & Needs human intervention to become clean \\
Mostly pure & 0.158 & 0.835 & Mostly contaminated \\
Recovers easily from human impacts & 0.086 & 0.858 & Recovers poorly from human impacts \\
\hline
\end{tabular}

across all ecotypes as more resilient than do nonwhite and white women. A similar pattern emerges with respect to the perceived resilience of water and soil. Figure 3 provides that variation using the example of soil.

Fig. 3. Perceived resilience of soil across ecotypes by gender and race. All males consistently regard the resilience of air, water, and soil across all ecotypes as more resilient than do all nonwhite and white females.

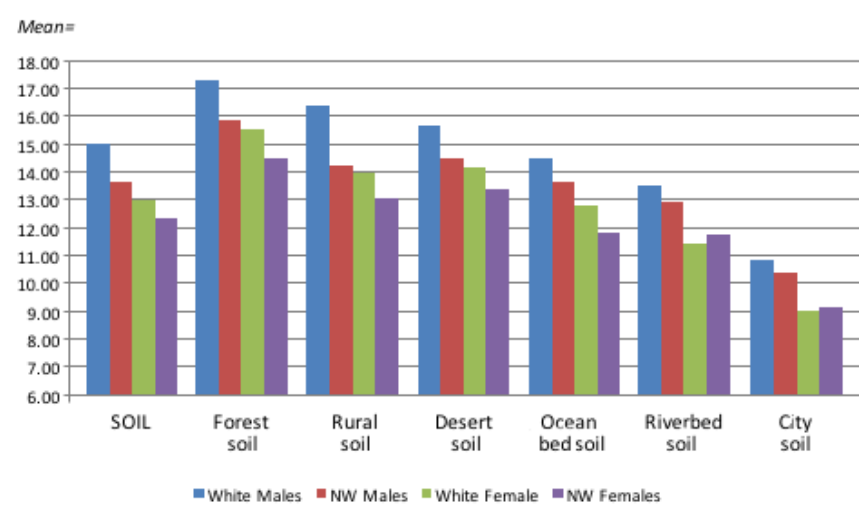

In all cases city soil, air, and water are seen as considerably less resilient than are all other ecotypes, with that difference being particularly stark when considering the views of city air and water among white and nonwhite women ( $M=$ approximately 7.0 ). These results are consistent with earlier studies of the perceived risk of new technologies, wherein white males regard most hazards as riskier than do nonwhite males, white and nonwhite women (Flynn et al. 1994, Finucane et al. 2000). Similarly, women express more concern about environmental harms than do most men (Davidson and Freudenburg 1996). Most of this demographic effect is explained in these earlier papers by political world views (white males who believe in authoritarian decision making and are politically conservative are particularly risk tolerant; Flynn et al. 1994, Finucane et al. 2000). Similarly, race and gender findings are also explained by men and women who regard themselves as vulnerable and/or who believe in the existence of environmental injustices (Satterfield et al. 2004). Although we did not have the space in this study for an investigation of this kind, in the future we would investigate whether race and gender are proxies in this case for these other views.

\section{Sensing resilience}

Ultimately, perception is an act of intuitively gleaning, evaluating, or sensing, be that sensing air, water, and soil or something else. Thus, our last analysis sought to investigate the relationship between the perceived resilience and tangibility of air, water, and soil across ecotypes, and the degree to which respondents believed they could detect the safety of the environment using their senses. To do this, we estimated three ordinary least squares (OLS) regressions for the perceived tangibility of air, water, and soil, and three OLS regressions for the perceived resilience of air, water, and soil, using the main independent variables: "senses help detect air safety," "senses help detect water safety," and "senses help detect soil safety." For control variables, we included age, education, income, nonwhite males (versus white males), white females (versus white males), and nonwhite females (versus white males).

As with results above, OLS coefficients confirm that nonwhite males as well as white and nonwhite females are considerably more likely to see air, water, and soil as less resilient media than are white males. The more liberal one's ideology, the more likely one is to also regard these environmental media as relatively nonresilient. As well, respondents who believe their senses help them detect the safety of air and water (but not soil) are significantly more likely to believe that these systems are more resilient. In addition, they are significantly more likely to believe that air and water are more tangible. The variance explained by these regression models are, also, considerably more robust for resilience than for tangibility (Table 6). The summary tangibility models explain only $4-8 \%$ of the variance, whereas the summary resilience models explain $18-24 \%$ of the variance.

\section{DISCUSSION}

Apprehending environmental phenomena and perceiving resilience A growing interest in the social sciences in human cognition has produced considerable work addressing the rapid heuristic-based filters we use to process information (Gilovich et al. 2002), address the complexity of stimuli in the real world (Levine et al. 2015), and understand how we simplify that complexity when providing judgments of the good' or 'bad, or positive or negative qualities 
Table 6. Pattern matrix for ordinary least squares (OLS) findings. Perceived tangibility and resilience $\mathrm{x}$ belief in ability of senses to detect harm. Three estimated OLS regressions for the perceived tangibility of air, water, and soil, and 3 OLS regressions for the perceived resilience of air, water, and soil, using the main independent variables: "senses help detect [air, water, and soil] safety." Control variables included age, education, income, nonwhite males (vs. white males), white females (vs. white males), and nonwhite females (vs. white males).

\begin{tabular}{|c|c|c|c|c|c|c|c|}
\hline \multirow[b]{2}{*}{ VARIABLES } & Air is (more) & $\begin{array}{l}\text { Water is } \\
\text { (more) }\end{array}$ & Soil is (more) & \multirow[b]{2}{*}{ VARIABLES } & \multirow{2}{*}{$\begin{array}{c}\text { Air is (more) } \\
\text { Resilient }\end{array}$} & \multirow{2}{*}{$\begin{array}{l}\text { Water is } \\
\text { (more) }\end{array}$} & \multirow{2}{*}{ Soil is (more) } \\
\hline & Tangible & Tangible & Tangible & & & & \\
\hline Age & $\begin{array}{c}0.07 * * * \\
(0.01)\end{array}$ & $\begin{array}{l}-0.00 \\
(0.01)\end{array}$ & $\begin{array}{l}-0.01 \\
(0.01)\end{array}$ & Age & $\begin{array}{c}0.00 \\
(0.01)\end{array}$ & $\begin{array}{l}-0.00 \\
(0.01)\end{array}$ & $\begin{array}{c}-0.02^{* *} \\
(0.01)\end{array}$ \\
\hline Education & $\begin{array}{c}0.15 \\
(0.10)\end{array}$ & $\begin{array}{c}0.16 \\
(0.10)\end{array}$ & $\begin{array}{l}0.22^{*} \\
(0.10)\end{array}$ & Education & $\begin{array}{c}0.03 \\
(0.08)\end{array}$ & $\begin{array}{l}-0.08 \\
(0.08)\end{array}$ & $\begin{array}{c}0.06 \\
(0.08)\end{array}$ \\
\hline Income & $\begin{array}{l}-0.00 \\
(0.04)\end{array}$ & $\begin{array}{c}0.11 * * \\
(0.04)\end{array}$ & $\begin{array}{l}0.10^{*} \\
(0.04)\end{array}$ & Income & $\begin{array}{c}0.12 * * \\
(0.04)\end{array}$ & $\begin{array}{c}0.14 * * * \\
(0.04)\end{array}$ & $\begin{array}{c}0.14 * * * \\
(0.03)\end{array}$ \\
\hline $\begin{array}{l}\text { NW Male vs. White } \\
\text { Male }\end{array}$ & -0.14 & $-1.49 * * *$ & $-1.25^{* *}$ & $\begin{array}{l}\text { NW Male vs. White } \\
\text { Male }\end{array}$ & $-1.08 * *$ & $-1.02 * *$ & $-0.97 * *$ \\
\hline & $(0.42)$ & $(0.41)$ & $(0.42)$ & & $(0.34)$ & $(0.34)$ & $(0.32)$ \\
\hline $\begin{array}{l}\text { White Female vs. } \\
\text { White Male }\end{array}$ & $-2.08 * * *$ & $-0.79^{*}$ & $-0.69 *$ & $\begin{array}{l}\text { White Female vs. } \\
\text { White Male }\end{array}$ & $-2.14 * * *$ & $-2.29 * * *$ & $-1.73 * * *$ \\
\hline & $(0.32)$ & $(0.31)$ & $(0.31)$ & & $(0.26)$ & $(0.25)$ & $(0.24)$ \\
\hline $\begin{array}{l}\text { NW Female vs. } \\
\text { White Male }\end{array}$ & $-1.28 * *$ & -0.66 & -0.84 & $\begin{array}{l}\text { NW Female vs. } \\
\text { White Male }\end{array}$ & $-2.90 * * *$ & $-2.13 * * *$ & $-1.91 * * *$ \\
\hline & $(0.45)$ & $(0.44)$ & $(0.44)$ & & $(0.36)$ & $(0.36)$ & $(0.34)$ \\
\hline Liberal ideology & $\begin{array}{l}-0.13 \\
(0.15)\end{array}$ & $\begin{array}{l}-0.10 \\
(0.14)\end{array}$ & $\begin{array}{l}-0.07 \\
(0.14)\end{array}$ & Liberal ideology & $\begin{array}{l}-1.11^{* * *} \\
(0.12)\end{array}$ & $\begin{array}{c}-0.99 * * * \\
(0.12)\end{array}$ & $\begin{array}{c}-0.87 * * * \\
(0.11)\end{array}$ \\
\hline Democrat & $\begin{array}{c}0.14 \\
(0.21)\end{array}$ & $\begin{array}{c}-0.53 * * \\
(0.21)\end{array}$ & $\begin{array}{c}-0.65^{* *} \\
(0.21)\end{array}$ & Democrat & $\begin{array}{c}-0.53 * * \\
(0.17)\end{array}$ & $\begin{array}{l}-0.32 \\
(0.17)\end{array}$ & $\begin{array}{c}-0.62 * * * \\
(0.16)\end{array}$ \\
\hline $\begin{array}{l}\text { Senses detect air } \\
\text { safety }\end{array}$ & $0.62^{* * *}$ & $0.37^{*}$ & 0.31 & $\begin{array}{l}\text { Senses detect air } \\
\text { safety }\end{array}$ & $0.80 * * *$ & $0.70 * * *$ & 0.25 \\
\hline & $(0.17)$ & $(0.16)$ & $(0.17)$ & & $(0.14)$ & $(0.13)$ & $(0.13)$ \\
\hline $\begin{array}{l}\text { Senses detect water } \\
\text { safety }\end{array}$ & 0.03 & -0.00 & -0.02 & $\begin{array}{l}\text { Senses detect water } \\
\text { safety }\end{array}$ & -0.12 & -0.08 & 0.03 \\
\hline & $(0.17)$ & $(0.16)$ & $(0.16)$ & & $(0.14)$ & $(0.13)$ & $(0.13)$ \\
\hline $\begin{array}{l}\text { Senses detect soil } \\
\text { safety }\end{array}$ & 0.10 & $-0.38 *$ & $-0.45^{* *}$ & $\begin{array}{l}\text { Senses detect soil } \\
\text { safety }\end{array}$ & $0.39 * *$ & $0.37 * *$ & $0.54 * * *$ \\
\hline & $(0.17)$ & $(0.16)$ & $(0.16)$ & & $(0.13)$ & $(0.13)$ & $(0.12)$ \\
\hline Constant & $\begin{array}{l}9.76 * * * \\
(0.76)\end{array}$ & $\begin{array}{l}23.74 * * * \\
(0.74)\end{array}$ & $\begin{array}{l}25.13^{* * *} \\
(0.73)\end{array}$ & Constant & $\begin{array}{l}13.35^{* * * *} \\
(0.61)\end{array}$ & $\begin{array}{c}14.23^{* * *} * \\
(0.60)\end{array}$ & $\begin{array}{l}15.12 * * * \\
(0.57)\end{array}$ \\
\hline Observations & 1,815 & 1,825 & 1,832 & Observations & 1,843 & 1,837 & 1,833 \\
\hline Adjusted R-squared & 0.075 & 0.034 & 0.036 & Adjusted R-squared & 0.238 & 0.198 & 0.184 \\
\hline
\end{tabular}

of the world around us (Slovic et al. 2007). And perception itself includes many meanings (Bennett 2016, Ingold 2000), though we tend to agree with Ingold (2000) who argues that perception is neither innate nor acquired, but instead is incorporated into the human organism though practice and training in the environment, however varied that might be.

What we found here, across two sequential studies, is that there might well be some rapid and intuitive bases through which people detect how fully an environment is apprehendable to them (aka its tangibility). We were able to convert the loosely articulated explanations (from interviews) of some of what makes environments variable. That is, people do see or detect different environments as more or less the touchable, visible, testable, describable, and measureable. There are some environments, we interpret, that we can literally and figuratively get our sensing selves around, to put it colloquially, and some we cannot. This is not surprising, perhaps, to the extent that air is less tangible by its very nature. What is perhaps more interesting is that some environments (e.g., forests or at least forest air, water, and soil) come easily to mind, are imagined more completely and physically, that is, tangibly, than are others, for example, oceans or deserts. Deserts are sparsely populated environments and so this might well make sense, but much of the U.S. population sampled here lives in coastal or ocean-near environments and so our logic does not hold. As well, some part of these judgements is explained by the degree to which we believe in the capacity of our senses to detect harm. Regardless, these differences, although significant, need considerable refinement.

Our investigation of resilience is perhaps more revealing and useful. Resilience is an important master construct in the management of coupled human-natural systems, but it might also be a more widely intuitive one. We found resilience to be a construct key to respondents' evaluation of forests, as compared to deserts, oceans, river, rural or urban environments. The factor components suggest that people have their own heuristic filters for evaluating and distinguishing systems as pure or not, healthy or not, amenable to recovery from human impacts, or necessitating human intervention to achieve that recovery. Last, 
resilience is a quality projected differently onto these environments when the perceiver is male versus female or white versus Latina/Latino, African American, or Asian. That is, environments in the form of the ecotypes tested here are, in general, regarded as less resilient by everyone, relative to white males.

However much these results should be regarded as a first effort, what matters here is the possibility that resilience may be developed not only as a biophysical construct but as an intuitive or perceptual one. If indeed we do see forests as more robust in the face of harms than oceans, the implications for scientific and environmental communication are many. Are forests overly assumed to be the lungs of world that can absorb most harms? Are oceans misperceived and so imagined out there as a vast dispensary for rogue disposal of contaminants? Perhaps yes in both cases. Receiving news of environmental harms can only of late be seen as a constant, but what we hear and why is a nontrivial question. It might well affect how we evaluate the siting of different development projects, what we judge as a significant harmful activity, and where we invest in conservation. Certainly, similar experiments have looked at the power of some visual images as they affect, for instance, one's sense of urgency regarding climate change (Sheppard 2005).

More academically, it remains an open empirical question as to whether this operationalizing of resilience is a meaningful index as compared to other independent variables used in survey research. Is resilience, for example, a discriminating driver of people's reported concerns regarding different environmental problems (e.g., climate change or biodiversity loss) as compared to other well-known indices such as the New Ecological Paradigm (Dunlap et al. 2000, Poortinga et al. 2002), measures of place attachment (Scannell and Gifford 2013), or a variety of value classifications and their indices (Dietz et al. 2005)? Second, developing a basis for understanding perceived resilience will likely benefit our analysis of social-ecological systems. Increasingly, our world is global thus understanding how distant drivers of environmental change are perceived, ignored, or intuited by distant actors as well as local ones, may be useful. For example, a means for rapidly collecting quantitative measures of perceived system resilience might well prove to be a wise heuristic of what people think matters and why, and where communication and our literacy about different problems might well be improved. An elaborated measure may or may not align with expert definitions of resilience, but if so that is important and useful information.

In retrospect, we also harbor all manner of afterthoughts, which will hopefully serve future studies. First, the very act of referring to the environment in terms of its most base components, air, water, and soil, is probably too abstract a basis for understanding intuitive characterizations of environmental contexts. We know already from a vast case study literature that "the environment" is rarely imagined by different publics as comprising these material basics, but rather in reference to more affectively loaded histories of land use, meaning making, and material properties (Brehm et al. 2013). That is, the environment is usually thought of and described in reference to specific physical settings that inspire place attachment (Basso 1996, Brown and Raymond 2007, Devine-Wright and Howes 2010), that embody iconic properties such as wildness (e.g., the Arctic) or as sites that have been stigmatized by industrial accidents or pollution (e.g., widespread pesticide use; Colocousis 2012, Sultana 2012, Vandermoere and Vanderstraeten 2014). An interesting prospect is to trial a more theoretically accurate application of resilience. The components of perception captured here do not reflect, for instance, ideas of regime change or thresholds or response to events such as the rapid escalation of an invading species. Are there heuristics that people use, for example, to detect a regime at the edge of change and if so what might these be: signs of an invasive pest in a tree canopy, abundance of non-native species, or other signals we might rely on (accurately or not) to detect significant change? Ultimately this matters as people act on what they perceive to be true (Lee et al. 2015). It might also be useful to see whether specific well-known sites are evaluated on terms associated with resilience as sensitivity to change or thresholds might be more powerful when place attachment is strong. Nor are we sure that our rating scales are those most useful or accurate with regard to people's intuitions. Do the four-reduced-to-two initial factors reported here hold true given more realistic and better described or visually represented environmental contexts? Alternately, how might these elicited intuitions about environmental media be compared to other independent variables predicting perceived environmental risk? Regardless, it should not be the case that perceived risks to the environment and risks to human health are conflated such that the former is invariably studied as the vector of the latter, rather than as a discrete class of risk understanding in its own right. How we intuitively know or read many environmental contexts might well reveal new understandings of perception about our immediate and imagined natural worlds.

Responses to this article can be read online at: http://www.ecologyandsociety.org/issues/responses. php/10637

\begin{abstract}
Acknowledgments:
Funding was provided by NSF and EPA cooperative agreement \#DBI 0830117 to the University of California at Santa Barbara, and University of California-LA. Additional support provided by US National Science Foundation through cooperative agreement \#SES 0938099; and a Social Sciences and Humanities Council of Canada award (\#435-20132017). We would also like to thank Shannon Hana and Lauren Copeland for help with data analysis at an earlier stage of work, and Laura DeVries and Gwen D'Arcangeles for conducting interviews. Milind Kandlikar and Nick Pidgeon were inspirational colleagues during much of this work as well.
\end{abstract}

\section{LITERATURE CITED}

Adger, W. N. 2006. Vulnerability. Global Environmental Change 16:268-281. http://dx.doi.org/10.1016/j.gloenvcha.2006.02.006

Armitage, D. 2005. Adaptive capacity and community-based natural resource management. Environmental Management 35:703-715. http://dx.doi.org/10.1007/s00267-004-0076-Z

Arshad, M. A., B. Lowery, and B. Grossman. 1996. Physical tests for monitoring soil quality. Methods for Assessing Soil Quality 123-141. 
Axt, J. R., C. R. Ebersole, and B. A. Nosek. 2014. The rules of implicit evaluation by race, religion, and age. Psychological Science 25:1804-1815. http://dx.doi.org/10.1177/0956797614543801

Bamberg, S. and G. Möser. 2007. Twenty years after Hines, Hungerford, and Tomera: a new meta-analysis of psycho-social determinants of pro-environmental behaviour. Journal of Environmental Psychology 27:14-25. http://dx.doi.org/10.1016/j. jenvp.2006.12.002

Basso, K. H. 1996. Wisdom sits in places: landscape and language among the Western Apache. University of New Mexico Press, Albuquerque, New Mexico, USA.

Basurto, X. 2013. Linking multi-level governance to local common-pool resource theory using fuzzy-set qualitative comparative analysis: insights from twenty years of biodiversity conservation in Costa Rica. Global Environmental Change 23 (3):573-587. http://dx.doi.org/10.1016/j.gloenvcha.2013.02.011

Bennett, N. J. 2016. Using perceptions as evidence to improve conservation and environmental management. Conservation Biology 30:582-592. http://dx.doi.org/10.1111/cobi.12681

Bennett, N. J., P. Dearden, G. Murray, and A. Kadfak. 2014. The capacity to adapt?: communities in a changing climate, environment, and economy on the northern Andaman coast of Thailand. Ecology and Society 19(2):5. http://dx.doi.org/10.5751/ ES-06315-190205

Berkes, F., J. Colding, and C. Folke. editors. 2003. Navigating social-ecological systems: building resilience for complexity and change. Cambridge University Press, Cambridge, UK. http://dx. doi.org/10.1017/CBO9780511541957

Berkes, F., C. Folke, and M. Gadgil. 1995. Traditional ecological knowledge, biodiversity, resilience and sustainability. Biodiversity Conservation 281-299. http://dx.doi.org/10.1007/978-94-011-0277-3 15

Bickerstaff, K. 2004. Risk perception research: socio-cultural perspectives on the public experience of air pollution. Environment International 30:827-840. http://dx.doi.org/10.1016/ j.envint.2003.12.001

Blythe, J. L. 2015. Resilience and social thresholds in small-scale fishing communities. Sustainability Science 10:157-165. http://dx. doi.org/10.1007/s11625-014-0253-9

Bodemer, N., and W. Gaissmaier. 2015. Risk perception. Pages 10-23 in H. Cho, T. Reimer, K. A. McComas, editors. The Sage handbook of risk communication. Sage, Thousand Oaks, California, USA.

Brehm, J. M., B. W. Eisenhauer, and R. C. Stedman. 2013. Environmental concern: examining the role of place meaning and place attachment. Society \& Natural Resources 26:522-538. http:// dx.doi.org/10.1080/08941920.2012.715726

Brown, G., and C. Raymond. 2007. The relationship between place attachment and landscape values: toward mapping place attachment. Applied Geography 27:89-111. http://dx.doi. org/10.1016/j.apgeog.2006.11.002

Castree, N., W. M. Adams, J. Barry, D. Brockington, B. Büscher, E. Corbera, D. Demeritt, R. Duffy, U. Felt, K. Neves, et al. 2014. Changing the intellectual climate. Nature Climate Change 4:763-768. http://dx.doi.org/10.1038/nclimate2339
Chan, K. M. A., P. Balvanera, K. Benessaiah, M. Chapman, S. Díaz, E. Gómez-Baggethun, R. Gould, N. Hannahs, K. Jax, S. Klain, et al. 2016. Opinion: why protect nature? Rethinking values and the environment. Proceedings of the National Academy of Sciences 113:1462-1465. http://dx.doi.org/10.1073/pnas.1525002113

Chapman, D. V. and World Health Organization (WHO). 1996. Water quality assessments: a guide to the use of biota, sediments and water in environmental monitoring.

Cobb, M. D. 2005. Framing effects on public opinion about nanotechnology. Science Communication 27(2):221-239. http:// dx.doi.org/10.1177/1075547005281473

Colocousis, C. R. 2012. "It was tourism repellent, that's what we were spraying": natural amenities, environmental stigma, and redevelopment in a postindustrial mill town. Sociological Forum 27:756-776. http://dx.doi.org/10.1111/j.1573-7861.2012.01344.x

Conti, J., T. Satterfield, and B. H. Harthorn. 2011. Vulnerability and social justice as factors in emergent U.S. nanotechnology risk perceptions. Risk Analysis 31:1734-1748. http://dx.doi.org/10.1111/ j.1539-6924.2011.01608.x

Daily, G. C., T. Söderqvist., S. Aniyar, K. Arrow, P. Dasgupta, P. Ehrlich, C. Folke, A, Jansson, B. Jansson, N. Kautsky, S. Levin, J. Lubchenco, K.-G. Mäler, D. Simpson, D. Starrett, D. Tilman, and B. Walker. 2000. The value of nature and the nature of value. Science 289:395-396. http://dx.doi.org/10.1126/science.289.5478.395

Davidson, D. J., and W. R. Freudenburg. 1996. Gender and environmental risk concerns: a review and analysis of available research. Environment and Behavior 28:302-339. http://dx.doi. org/10.1177/0013916596283003

de Groot, R. S., M. A. Wilson, and R. M. Boumans. 2002. A typology for the classification, description and valuation of ecosystem functions, goods and services. Ecological Economics 41:393-408. http://dx.doi.org/10.1016/S0921-8009(02)00089-7

Devine-Wright, P., and Y. Howes. 2010. Disruption to place attachment and the protection of restorative environments: a wind energy case study. Journal of Environmental Psychology 30:271-280. http://dx.doi.org/10.1016/j.jenvp.2010.01.008

Dietz, T., A. Fitzgerald, and R. Shwom. 2005. Environmental values. Annual Review of Environment and Resources 30:335-372. http://dx.doi.org/10.1146/annurev.energy.30.050504.144444

Dunlap, R. E., K. D. Van Liere, A. G. Mertig, and R. E. Jones. 2000. New trends in measuring environmental attitudes: measuring endorsement of the new ecological paradigm: a revised NEP scale. Journal of Social Issues 56:425-442. http://dx.doi. org/10.1111/0022-4537.00176

Durant, R. F. and D. J. Fiorino. 2017. Environmental governance reconsidered: challenges, choices, and opportunities. MIT Press, Cambridge, Massachusetts, USA.

Echeverri, A., M. M. Callahan, K. M. A. Chan, T. Satterfield, and J. Zhao. 2017. Explicit not implicit preferences predict conservation intentions for endangered species and biomes. PLoS ONE 12(1):e0170973. http://dx.doi.org/10.1371/journal.pone.0170973

Engle, N. L. 2011. Adaptive capacity and its assessment. Global Environmental Change 21:647-656. http://dx.doi.org/10.1016/j. gloenvcha.2011.01.019 
Failing, L., R. Gregory, and P. Higgins. 2013. Science, uncertainty, and values in ecological restoration: a case study in structured decision-making and adaptive management. Restoration Ecology 21(4):422-430. http://dx.doi.org/10.1111/j.1526-100X.2012.00919. $\underline{\mathrm{x}}$

Finucane, M. L., P. Slovic, C. K. Mertz, J. Flynn, and T. A. Satterfield. 2000. Gender, race, and perceived risk: the 'white male' effect. Health, Risk \& Society 2:159-172. http://dx.doi. org/10.1080/713670162

Fischhoff, B. 1991. Value elicitation: Is there anything in there? American Psychologist 46:835-847. http://dx.doi. org/10.1037/0003-066X.46.8.835

Flynn, J., P. Slovic, and C. K. Mertz. 1994. Gender, race, and perception of environmental health risks. Risk Analysis 14:1101-1108. http://dx.doi.org/10.1111/j.1539-6924.1994.tb00082. $\underline{\mathrm{x}}$

Folke, C., S. Carpenter, B. Walker, M. Scheffer, T. Elmqvist, L. Gunderson, and C. S. Holling. 2004. Regime shifts, resilience, and biodiversity in ecosystem management. Annual Review of Ecology, Evolution, and Systematics 35:557-581. http://dx.doi. org/10.1146/annurev.ecolsys.35.021103.105711

Gilovich, T., D. Griffin, and D. Kahneman, editors. 2002. Heuristics and biases: the psychology of intuitive judgment. Cambridge University Press, Cambridge, UK. http://dx.doi. org/10.1017/CBO9780511808098

Greenwald, A. G., T. A. Poehlman, E. L. Uhlmann, and M. R. Banaji. 2009. Understanding and using the implicit association test: III. Meta-analysis of predictive validity. Journal of Personality and Social Psychology 97:17-41. http://dx.doi. org/10.1037/a0015575

Gregory, R., and K. Wellman. 2001. Bringing stakeholder values into environmental policy choices: a community-based estuary case study. Ecological Economics 39:37-52. http://dx.doi. org/10.1016/S0921-8009(01)00214-2

Hohenemser, C., R. Goble, J. X. Kasperson, R. E. Kasperson, R. W. Kates, P. Collins, A. Goldman, P. Slovic, B. Fischhoff, S. Lichtenstein, and M. Layman. 1986. Methods for analyzing and comparing technological hazards. Risk Evaluation and Management 249-274. http://dx.doi.org/10.1007/978-1-4613-2103-3_10

Ingold, T. 2000. The perception of the environment: essays on livelihood, dwelling and skill. Psychology Press, London, UK. http://dx.doi.org/10.4324/9780203466025

Johnson, B. B., and V. T. Covello, editors. 2012. The social and cultural construction of risk: essays on risk selection and perception (Vol. 3). Klumer Academic, Dordrecht, The Netherlands.

Kahan, D. 2010. Fixing the communications failure. Nature 463:296-297. http://dx.doi.org/10.1038/463296a

Kahan, D. M. 2014. Making climate-science communication evidence-based: all the way down. Pages 203-220 in D. A. Crow and M. T. Boykoff, editors. Culture, politics and climate change: how information shapes our common future. Earthscan, London, UK. http://dx.doi.org/10.2139/ssrn.2216469
Kahneman, D. 2003. A perspective on judgment and choice: mapping bounded rationality. American Psychologist 58:697-720. http://dx.doi.org/10.1037/0003-066X.58.9.697

Kaiser, H. F. 1974. An index of factorial simplicity. Psychometrika 39:31-36. http://dx.doi.org/10.1007/BF02291575

Kalof, L., and T. Satterfield, editors. 2005. The Earthscan reader in environmental values. Earthscan, London, UK.

Kaplan-Hallam, M., N. J. Bennett, and T. Satterfield. 2017. Catching sea cucumber fever in coastal communities: conceptualizing the impacts of shocks versus trends on socialecological systems. Global Environmental Change 45:89-98. http:// dx.doi.org/10.1016/j.gloenvcha.2017.05.003

Keller, C., A. Bostrom, M. Kuttschreuter, L. Savadori, A. Spence, and M. White. 2012. Bringing appraisal theory to environmental risk perception: a review of conceptual approaches of the past 40 years and suggestions for future research. Journal of Risk Research 15(3):237-256. http://dx.doi.org/10.1080/13669877.2011.634523

Klain, S. C., P. Olmsted, K. M. Chan, and T. Satterfield. 2017. Relational values resonate broadly and differently than intrinsic or instrumental values, or the New Ecological Paradigm. PLoS ONE 12(8):e0183962. http://dx.doi.org/10.1371/journal.pone.0183962

Klain, S. C., T. A. Satterfield, and K. M. A. Chan. 2014. What matters and why? Ecosystem services and their bundled qualities. Ecological Economics 107:310-320. http://dx.doi.org/10.1016/j. ecolecon.2014.09.003

Knuth, D., D. Kehl, L. Hulse, and S. Schmidt. 2014. Risk perception, experience, and objective risk: a cross-national study with European emergency survivors. Risk Analysis 34:1286-1298. http://dx.doi.org/10.1111/risa.12157

Lee, T. M., E. M. Markowitz, P. D. Howe, C.-Y. Ko, and A. A. Leiserowitz. 2015. Predictors of public climate change awareness and risk perception around the world. Nature Climate Change 5:1014-1020. http://dx.doi.org/10.1038/nclimate2728

Leiserowitz, A. 2007. International public opinion, perception, and understanding of global climate change. Human Development Report 31:1-40.

Lemos, M. C., and A. Agrawal. 2006. Environmental governance. Annual Review of Environment and Resources 31:297-325. http:// dx.doi.org/10.1146/annurev.energy.31.042605.135621

Levine, J., K. M. A. Chan, and T. Satterfield. 2015. From rational actor to efficient complexity manager: exorcising the ghost of Homo economicus with a unified synthesis of cognition research. Ecological Economics 114:22-32. http://dx.doi.org/10.1016/j. ecolecon.2015.03.010

Liu, J., T. Dietz, S. R. Carpenter, M. Alberti, C. Folke, E. Moran, A. N. Pell, P. Deadman, T. Kratz, J. Lubchenco, et al. 2007. Complexity of coupled human and natural systems. Science 317:1513-1516. http://dx.doi.org/10.1126/science.1144004

Lockwood, M. 1999. Humans valuing nature: synthesising insights from philosophy, psychology and economics. Environmental Values 8:381-401. http://dx.doi.org/10.3197/0963$\underline{27199129341888}$ 
Loewenstein, G. F., E. U. Weber, C. K. Hsee, and N. Welch. 2001. Risk as feelings. Psychological Bulletin 127:267-286. http://dx.doi. org/10.1037/0033-2909.127.2.267

Macoubrie, J. 2006. Nanotechnology: public concerns, reasoning and trust in government. Public Understanding of Science 15:221-241. http://dx.doi.org/10.1177/0963662506056993

Marshall, G. 2015. Don't even think about it: why our brains are wired to ignore climate change. Bloomsbury, New York, New York, USA.

Marshall, N. A., M. Friedel, R. D. van Klinken, and A. C. Grice. 2011. Considering the social dimension of invasive species: the case of buffel grass. Environmental Science \& Policy 14:327-338. http://dx.doi.org/10.1016/j.envsci.2010.10.005

McDaniels, T., L. J. Axelrod, and P. Slovic. 1995. Characterizing perception of ecological risk. Risk Analysis 15:575-588. http://dx. doi.org/10.1111/j.1539-6924.1995.tb00754.x

McGinnis, M. D., and E. Ostrom. 2014. Social-ecological system framework: initial changes and continuing challenges. Ecology and Society 19(2):30. http://dx.doi.org/10.5751/ES-06387-190230

Miller, F., H. Osbahr, E. Boyd, F. Thomalla, S. Bharwani, G. Ziervogel, B. Walker, J. Birkmann, S. Van der Leeuw, J. Rockström, J. Hinkel, T. Downing, C. Folke, and D. Nelson. 2010. Resilience and vulnerability: complementary or conflicting concepts? Ecology and Society 15(3):11. http://dx.doi. org/10.5751/ES-03378-150311

Naidoo, R., and T. H. Ricketts. 2006. Mapping the economic costs and benefits of conservation. PLoS Biology 4(11):e360. http://dx. doi.org/10.1371/journal.pbio.0040360

Niemeyer, S., and C. L. Spash. 2001. Environmental valuation analysis, public deliberation, and their pragmatic syntheses: a critical appraisal. Environment and Planning C: Government and Policy 19:567-585.

O'Neill, J., A. Holland, and A. Light. 2007. Environmental values. Routledge, London, UK. http://dx.doi.org/10.4324/9780203495452

Oreg, S., and T. Katz-Gerro. 2006. Predicting proenvironmental behavior cross-nationally: values, the theory of planned behavior, and value-belief-norm theory. Environment and Behavior 38:462-483. http://dx.doi.org/10.1177/0013916505286012

Ostrom, E., J. Burger, C. B. Field, R. B. Norgaard, and D. Policansky. 1999. Revisiting the commons: local lessons, global challenges. Science 284:278-282. http://dx.doi.org/10.1126/ science.284.5412.278

Pidgeon, N. F., I. Lorenzoni, and W. Poortinga. 2008. Climate change or nuclear power-no thanks! A quantitative study of public perceptions and risk framing in Britain. Global Environmental Change 18:69-85. http://dx.doi.org/10.1016/j. gloenvcha.2007.09.005

Poortinga, W., and N. F. Pidgeon. 2005. Trust in risk regulation: cause or consequence of the acceptability of GM food? Risk Analysis 25:199-209. http://dx.doi.org/10.1111/j.0272-4332.2005.00579. $\underline{\mathrm{X}}$

Poortinga, W., L. Steg, and C. Vlek. 2002. Environmental risk concern and preferences for energy-saving measures. Environment and Behavior 34:455-478. http://dx.doi.org/10.1177/00116502034004003
Priest, S. 2006. The North American opinion climate for nanotechnology and its products: opportunities and challenges. Journal of Nanoparticle Research 8:563-568. http://dx.doi. org/10.1007/s11051-005-9060-7

Priest, S., T. Lane, T. Greenhalgh, L. J. Hand, and V. Kramer. 2011. Envisioning emerging nanotechnologies: a three-year panel study of South Carolina citizens. Risk Analysis 31:1718-1733. http://dx.doi.org/10.1111/j.1539-6924.2011.01705.x

Reche, C., X. Querol, A. Alastuey, M. Viana, J. Pey, T. Moreno, S. Rodríguez, Y. González, R. Fernández-Camacho, J. de la Rosa, et al. 2011. New considerations for PM, black carbon and particle number concentration for air quality monitoring across different European cities. Atmospheric Chemistry and Physics 11:6207-6227. http://dx.doi.org/10.5194/acp-11-6207-2011

Reddy, S. M. W., J. Montambault, Y. J. Masuda, E. Keenan, W. Butler, J. R. B. Fisher, S. T. Asah, and A. Gneezy. 2017. Advancing conservation by understanding and influencing human behavior. Conservation Letters 10(2):248-256. http://dx.doi.org/10.1111/ conl.12252

Richardson, L., and J. Loomis. 2009. The total economic value of threatened, endangered and rare species: an updated metaanalysis. Ecological Economics 68:1535-1548. http://dx.doi. org/10.1016/j.ecolecon.2008.10.016

Sagoff, M. 1998. Aggregation and deliberation in valuing environmental public goods: a look beyond contingent pricing. Ecological Economics 24:213-230. http://dx.doi.org/10.1016/ $\underline{\text { S0921-8009(97)00144-4 }}$

Sagoff, M. 2007. The economy of the earth: philosophy, law, and the environment. Cambridge University Press, Cambridge, UK. http://dx.doi.org/10.1017/CBO9780511817472

Satterfield, T., M. Kandlikar, C. E. Beaudrie, J. Conti, and B. H. Harthorn. 2009. Anticipating the perceived risk of nanotechnologies. Nature Nanotechnology 4:752-758. http://dx. doi.org/10.1038/nnano.2009.265

Satterfield, T. A., C. K. Mertz, and P. Slovic. 2004. Discrimination, vulnerability, and justice in the face of risk. Risk Analysis 24:115-129. http://dx.doi.org/10.1111/j.0272-4332.2004.00416. $\underline{x}$

Scannell, L., and R. Gifford. 2013. Personally relevant climate change: the role of place attachment and local versus global message framing in engagement. Environment and Behavior 45 (1):60-85. http://dx.doi.org/10.1177/0013916511421196

Scheufele, D. A., E. A. Corley, S. Dunwoody, T. J. Shih, E. Hillback, and D. H. Guston. 2007. Scientists worry about some risks more than the public. Nature Nanotechnology 2:732-734. http://dx.doi.org/10.1038/nnano.2007.392

Schoon, M., and S. Van der Leeuw. 2015. The shift toward socialecological systems perspectives: insights into the human-nature relationship. Natures Sciences Sociétés 23:166-174. http://dx.doi. org/10.1051/nss/2015034

Sheppard, S. R. J. 2005. Landscape visualisation and climate change: the potential for influencing perceptions and behaviour. Environmental Science \& Policy 8:637-654. http://dx.doi. org/10.1016/j.envsci.2005.08.002 
Siegrist, M., A. Wiek, A. Helland, and H. Kastenholz. 2007. Risks and nanotechnology: the public is more concerned than experts and industry. Nature Nanotechnology 2:67. http://dx.doi. org/10.1038/nnano.2007.10

Slimak, M. W., and T. Dietz. 2006. Personal values, beliefs, and ecological risk perception. Risk Analysis 26(6):1689-1705. http:// dx.doi.org/10.1111/j.1539-6924.2006.00832.x

Slovic, P. 1987. Perception of risk. Science 236:280-285. http://dx. doi.org/10.1126/science. 3563507

Slovic, P. 2000. The perception of risk. Risk, society, and policy series. Earthscan, London, UK.

Slovic, P., M. L. Finucane, E. Peters, and D. G. MacGregor. 2007. The affect heuristic. European Journal of Operational Research 177:1333-1352. http://dx.doi.org/10.1016/j.ejor.2005.04.006

Stern, P. C. 2000. New environmental theories: toward a coherent theory of environmentally significant behavior. Journal of Social Issues 56:407-424. http://dx.doi.org/10.1111/0022-4537.00175

Stern, P. C., T. Dietz, T. Abel, G. A. Guagnano, and L. Kalof. 1999. A value-belief-norm theory of support for social movements: the case of environmentalism. Human Ecology Review 6:81-97.

Sultana, F. 2012. Producing contaminated citizens: toward a nature-society geography of health and well-being. Annals of the Association of American Geographers 102:1165-1172. http://dx. doi.org/10.1080/00045608.2012.671127

Tadaki, M., J. Sinner, and K. M. A. Chan. 2017. Making sense of environmental values: a typology of concepts. Ecology and Society 22(1):7. http://dx.doi.org/10.5751/ES-08999-220107

Thrush, S. F., J. E. Hewitt, P. K. Dayton, G. Coco, A. M. Lohrer, A. Norkko, J. Norkko, and M. Chiantore. 2009. Forecasting the limits of resilience: integrating empirical research with theory. Proceedings of the Royal Society B: Biological Sciences 276:3209-3217. http://dx.doi.org/10.1098/rspb.2009.0661

Trainor, S. F. 2006. Realms of value: conflicting natural resource values and incommensurability. Environmental Values 15:3-29. http://dx.doi.org/10.3197/096327106776678951

Troudet, J., P. Grandcolas, A. Blin, R. Vignes-Lebbe, and F. Legendre. 2017. Taxonomic bias in biodiversity data and societal preferences. Scientific Reports 7:9132. http://dx.doi.org/10.1038/ s41598-017-09084-6

Turner II, B. L., P. A. Matson, J. J. McCarthy, R. W. Corell, L. Christensen, N. Eckley, G. K. Hovelsrud-Broda, J. X. Kasperson, R. E. Kasperson, A. Luers, et al. 2003. Illustrating the coupled human-environment system for vulnerability analysis: three case studies. Proceedings of the National Academy of Sciences 100:8080-8085. http://dx.doi.org/10.1073/pnas.1231334100

Vandermoere, F., and R. Vanderstraeten. 2014. Back and forward to the future: an explorative study of public responses to urban groundwater contamination. Journal of Environmental Planning and Management 57:720-732. http://dx.doi.org/10.1080/0964056$\underline{8.2013 .763773}$
Warren, C., A. P. McGraw, and L. Van Boven. 2011. Values and preferences: defining preference construction. Wiley Interdisciplinary Reviews: Cognitive Science 2:193-205. http://dx.doi.org/10.1002/ wcs.98

Williams, I. D. and A. Bird. 2003. Public perceptions of air quality and quality of life in urban and suburban areas of London. Journal of Environmental Monitoring 5:253-259. http://dx.doi. org/10.1039/b209473h

World Health Organization (WHO). 2000. Air quality guidelines for Europe. World Health Organization Regional Office for Europe, Copenhagen, Denmark. 